\title{
Kegiatan Bakti Sosial Pembagian Masker Gratis: Upaya Pencegahan Penyebaran Covid-19 Di Kota Batam
}

\author{
Johannes Tarigan $^{1 *}$, Yusak Hentrias Ferry ${ }^{2}$, Yonatan Togodi ${ }^{3}$, Feberianus \\ Telaumbanua ${ }^{4}$ \\ 1,2,3,4 Prodi Teologi, STT Real Batam \\ *jhnnstarigan@gmail.com
}

\begin{abstract}
Batam Center Ferry Port is the place where this social service activity is carried out. This port is a gateway for foreigners and Indonesian citizens to go to neighboring countries. Therefore, the NGO PEDULI BANGSA is moved to help the government through community service activities in collaboration with the Indonesian Journalists Association and the Local Youth Association. The purpose of this service is to help the government to prevent the spread of the Covid-19 outbreak in the city of Batam. The forms and methods of the activities carried out are increasing public awareness about health by distributing free masks in the midst of the scarcity and high price of masks, then conducting counseling on how to use masks correctly. The result of this activity is an increase in public awareness about the importance of preventing the spread of the Covid-19 outbreak by wearing the right masks.

Keywords: Community Service, Distribution of Free Masks, Prevention, Spread of Covid-19, Batam City
\end{abstract}

\begin{abstract}
Abstrak
Pelabuhan Ferry Batam Center merupakan tempat kegiatan bakti sosial ini dilaksanakan. Pelabuhan ini merupakan gerbang keluar masuk bagi WNA dan WNI menuju negara tetangga. Oleh karena itu, LSM PEDULI BANGSA tergerak untuk membantu pemerintah melalui kegiatan pengabdian masyarakat dengan bekerja sama dengan Persatuan Wartawan Indonesia dan Persatuan Pemuda Tempatan. Tujuan dari pengabdian ini adalah membantu pemerintah untuk mencegah penyebaran wabah Covid-19 di kota Batam. Bentuk dan metode kegiatan yang dilakukan yaitu peningkatan kesadaran masyarakat tentang kesehatan dengan membagikan masker gratis di tengah-tengah kelangkaan dan mahalnya harga masker, kemudian melakukan penyuluhan cara menggunakan masker yang benar. Hasil dari kegiatan ini adalah peningkatan kesadaran masyarakat tentang pentingnya untuk mencegah penyebaran wabah Covid-19 dengan memakai masker yang benar.

Kata kunci: Bakti Sosial, Pembagian Masker Gratis, Pencegahan, Penyebaran Covid-19, Kota Batam
\end{abstract}

\section{PENDAHULUAN}

Wabah Covid-19 awalnya terdengar pada tanggal 31 Desember 2019, ketika seluruh dunia bersiap-siap untuk menyambut tahun baru 2020, China menyampaikan laporan ke Organisasi Kesehatan Dunia (WHO) mengenai adanya kasus pneumonia aneh di kota Wuhan. (WHO, Listing of WHO's response to COVID-19, 2020) Dikarenakan oleh meningkatnya penyebaran wabah ini di China dan penyebarannya ke negara-negara lain, WHO kemudian menetapkan Covid-19 menjadi Emergency of International Concern (PHEIC) pada tanggal 30 Januari 2020. ${ }^{1}$ Pada tanggal 5 Februari 2020, Universitas Johns Hopkins mencatat korban terinfeksi mencapai 23.892 kasus dan korban meninggal 492 orang secara global. ${ }^{2}$

Virus Corona-19 telah menyebar ke seluruh dunia, dan hanya beberapa negara kecil saja yang tidak terpapar virus tersebut. WHO sebagai organisasi kesehatan dunia telah menempuh berbagai cara untuk menanggulangi wabah COVID-19 ini, salah satunya yaitu dengan mengajak setiap negara untuk

\footnotetext{
${ }^{1}$ World Health Organization, Statement on the Second Meeting of the International Health Regulations (2005) Emergency Committee Regarding the Outbreak of Novel Coronavirus (2019-NCoV) (Geneva, 2020), https://www.who.int/news/item/30-01-2020-statement-on-the-second-meeting-of-the-international-healthregulations-(2005)-emergency-committee-regarding-the-outbreak-of-novel-coronavirus-(2019-ncov).

2 Julkifli Sinuhaji, "Update Virus Corona per 5 Februari 2020, Korban Meninggal Capai 492 Orang," Pikiran Rakyat.Com (Jakarta, 2020), https://www.pikiran-rakyat.com/internasional/pr-01337139/update-viruscorona-per-5-februari-2020-korban-meninggal-capai-492-orang.
} 
bersama-sama menanggulangi wabah virus Covid-19 ini. Pemerintah pun menyikapi hal ini dengan berupaya untuk mencegah penularan virus Covid-19 di Indonesia. Salah satu upaya tersebut adalah dengan menyarankan masyarakat untuk memakai masker saat beraktivitas di luar rumah. Hal ini menyebabkan meningkatnya kebutuhan masker yang akhirnya menimbulkan kelangkaan masker di pasaran dan harga masker pun melonjak tinggi. ${ }^{3}$ Akibatnya adalah banyak masyarakat yang tidak mampu untuk membeli dan akhirnya tidak menggunakan masker saat beraktivitas di luar rumah.

Pelabuhan Ferry Batam Center adalah tempat WNI dan WNA masuk dan keluar dari Batam, mereka bepergian dari dan ke Singapura serta Malaysia. Penyebaran wabah Covid-19 sangat rentan tersebar di lingkungan pelabuhan ini karena ramainya pelancong dari dalam dan luar negeri. Yang lebih memprihatinkan adalah masih banyak ditemukan orang-orang yang tidak memakai masker saat beraktivitas di tempat ini.

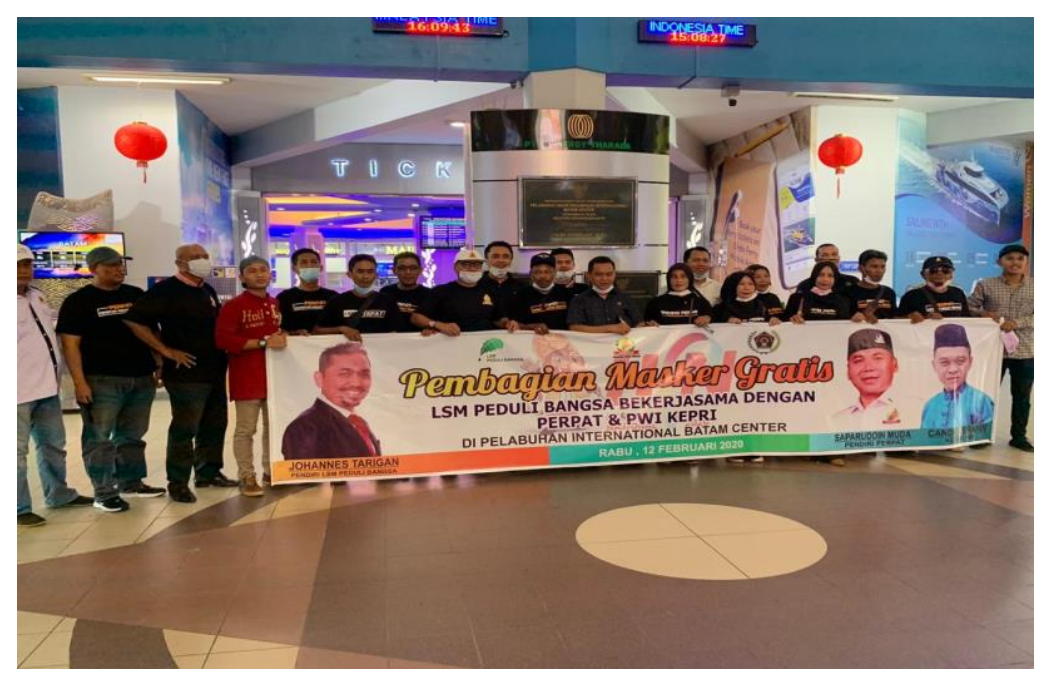

Gambar 1. Foto tim sebelum melakukan pembagian masker gratis

Berdasarkan kondisi dan situasi tersebut di atas , maka LSM Peduli Bangsa bersama PWI dan PERPAT bergerak mengadakan pengabdian masyarakat dengan berbagi 5000 masker gratis yang akan dibagikan kepada orang-orang yang tidak memakai masker di Pelabuhan Ferry Batam Center. Tidak hanya itu saja, tetapi juga memberikan edukasi kepada mereka bagaimana cara memakai masker yang benar.

Pengabdian masyarakat yang dilakukan oleh LSM Peduli Bangsa merupakan salah satu wujud kepedulian terhadap kebutuhan masyarakat dan panggilan untuk bekerja sama dengan pemerintah. Tujuan dari pengabdian ini adalah membantu pemerintah untuk mencegah penyebaran wabah Covid19 di kota Batam, targetnya dalam kegiatan bakti sosial ini adalah terjadi peningkatan kesadaran masyarakat tentang pentingnya untuk mencegah penyebaran wabah Covid-19 dengan memakai masker yang benar.

Dengan tercapainya target tersebut maka kemungkinan penyebaran virus Covid-19 akan semakin menurun di kota Batam. Manfaat dari pengabdian: 1) mencegah potensi penularan virus kepada mereka yang tidak memiliki masker 2) memberikan edukasi pentingnya memakai masker dan memakainya dengan benar 3) meringankan beban pemerintah dalam penanganan covid-19 di kota Batam.

\footnotetext{
${ }^{3}$ Fachrur Rozie, "Virus Corona Di Indonesia, Harga Masker Melonjak Hingga Rp 1,5 Juta," LIputan6.Com (Jakarta, 2020), https://www.liputan6.com/news/read/4192648/virus-corona-di-indonesia-hargamasker-melonjak-hingga-rp-15-juta.
} 


\section{METODE}

Metode pelaksanaan dalam program pengabdian masyarakat ini dimulai dengan mencari informasi dengan berdiskusi dengan PWI, PERPAT dan beberapa masyarakat tentang kondisi kesadaran masyarakat akan pentingnya memakai masker untuk mencegah penyebaran virus Covid-19. Berdasarkan informasi tersebut, LSM Peduli Bangsa memilih sasaran lokasi yang akan dijadikan tempat pembagian masker dan edukasi pemakaian masker yang benar. Sasaran pelaksanaan pengabdian masyarakat ini adalah orang-orang yang ada di Pelabuhan Ferry Batam Center (PFBC).

Kemudian tim menentukan waktu, hari dan tanggal, beserta titik pelaksanaan pengabdian masyarakat di PFBC. Selanjutnya tim melakukan survei lapangan langsung ke tempat pengabdian masyarakat yang telah ditentukan, serta berkoordinasi dengan pihak atasan PFBC untuk mendapatkan izin pelaksanaan kegiatan ini. Untuk pengadaan masker, tim melakukan pembelian masker dari beberapa penjual hingga terkumpul 5000 masker untuk dibagikan pada saat pelaksanaan kegiatan ini.

Pelayanan masyarakat ini dilaksanakan pada tanggal 12 Februari 2020 di Pelabuhan Ferry Batam Center. Pada kegiatan ini LSM Peduli Bangsa membagikan 5000 buah masker dan memberikan edukasi cara pemakaian masker yang benar kepada orang yang ada di PFBC. Kegiatan ini dilakukan dengan menerapkan protokol Kesehatan yang ketat.

Evaluasi dilakukan setelah kegiatan ini selesai dilaksanakan. Evaluasi ini bertujuan untuk mengukur keberhasilan dalam melaksanakan seluruh kegiatan. Salah satu cara mengukurnya adalah dengan memeriksa persediaan masker yang disiapkan dan juga melalui pemeriksaan laporan keuangan. Dan hasilnya terbukti bahwa masker tidak ada yang tersisa dan pengeluaran yang dicatat sudah sesuai data yang ada.

Aktivitas yang dilakukan oleh tim disambut baik oleh masyarakat yang ada di lokasi pelaksanaan pengabdian masyarakat ini. Beberapa dari mereka bahkan sangat berterima kasih kepada tim pengabdian Masyarakat dari LSM Peduli Bangsa atas kegiatan pembagian masker gratis ini.

\section{HASIL DAN PEMBAHASAN}

\section{Gambaran Umum Lokasi Penelitian}

Kegiatan bakti sosial yang dipelopori oleh LSM Peduli Bangsa yang berkolaborasi dengan PWI dan PERPAT ini adalah wujud panggilan mereka untuk mendukung pemerintah dalam mencegah penyebaran virus Covid-19 di kota Batam. Selain itu menggunakan masker adalah satu aturan yang telah laksanakan diseluruh dunia ${ }^{4}$, agar penyebaran Covid-19 ini tidak semakin meluas. Dengan melihat bahayanya penyebaran Covid-19 sehingga tim melaksanakan kegiatan ini sebagai rasa wujud sosial dan kemanusaiaan untuk menyedarkan masayarakat yang ada di Kota Batam. Kegiatan bakti sosial dilaksanakan pada pertengahan Februari 2020, tepatnya pada tanggal 12 Februari 2020. Kegiatan ini dilaksanakan di Pelabuhan Ferry Batam Center. Berikut ini adalah hasil dan pembahasan kegiatan yang dilakukan oleh tim pengabdian masyarakat, sebagai berikut:

1. Membagikan Masker Gratis.

\footnotetext{
${ }^{4}$ Joko Tri Atmojo et al., "Penggunaan Masker Dalam Pencegahan Dan Penanganan Covid-19: Rasionalitas, Efektivitas, Dan Isu Terkini," Avicenna : Journal of Health Research 3, no. 2 (2020): 84-95.
} 


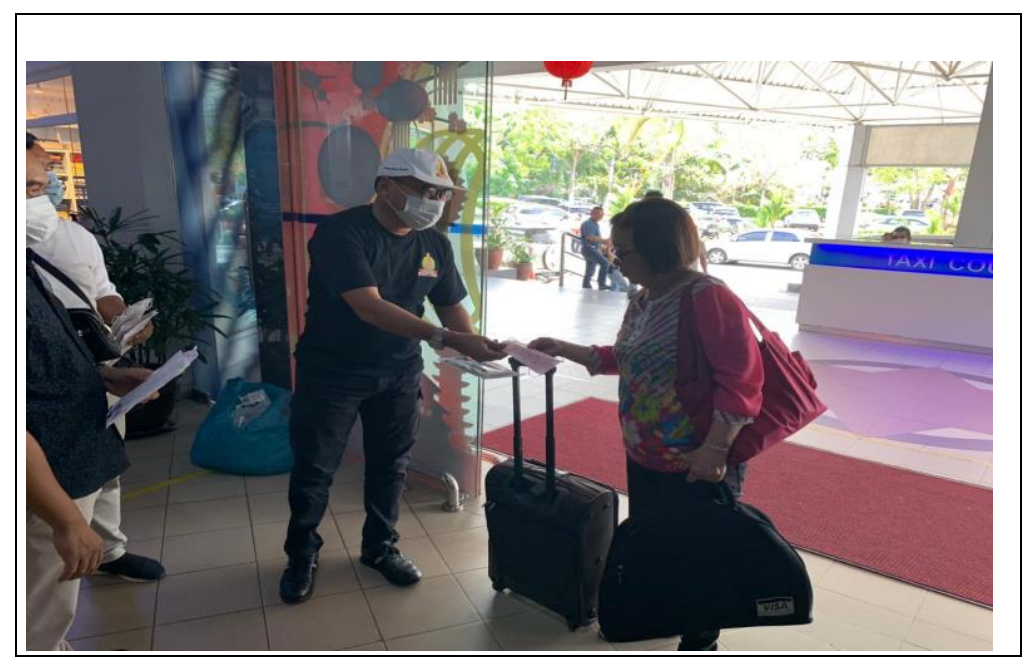

\section{Gambar 2. Foto Tim sedang membagikan masker kepada masyarakat}

Tim pelaksana memang menemukan begitu kurangnya kesadaran masyarakat terhadap bahayanya virus Covid-19. Hal ini jelas terlihat dari begitu banyaknya orang yang tidak memakai masker di lokasi pelaksanaan bakti sosial. Hal ini yang menyebabkan masyarakat yang ada di pelabuhan ini sangat rentan terhadap Covid-19 dan menjadi pembawa virus ini ke orang lain, ditambah lagi dengan adanya WNI dan WNA yang datang dari Singapura dan Malaysia. Makanya Wati, dkk menyarakan agar setiap masyarakat tetap menggunakan Alat Pelindung Diri (APD), yaitu masker untuk untuk memutus penularan Covid-19 ${ }^{5}$.

Menurut beberapa masyarakat yang ada di lokasi pelaksanaan, mereka tidak memakai masker dikarenakan karena beberapa sebab. Diantaranya adalah karena tidak mengetahui bahayanya virus Covid-19, harga masker yang melambung tinggi dan langkanya masker di pasaran. Hal ini memang merupakan fakta yang terjadi di tengah masyarakat di kota Batam. Akibatnya ada begitu banyak orang yang tidak memakai masker di lokasi ini. Sebenarnya hal-hal seperti ini bukan masalah mahalnya masker tetapi lebih kepada kesadaran masyarakat. Inilah yang dikomentar oleh Putri mengatakan bahwa setiap orang diwajibkan menggunakan masker dengan menutup wajah pada saat ada ditempat ${ }^{6}$.

Dengan hadirnya Tim di lapangan yang membagikan masker gratis kepada mereka, diharapkan hal ini dapat mengurangi resiko mereka tertular dan menularkan virus ini. Selain itu, hal ini diharapkan dapat meringankan beban mereka atas kelangkaan dan mahalnya harga masker di pasaran. Masyarakat yang menerima masker gratis sangat senang dan berterima kasih kepada tim khususnya mereka yang tahu bahayanya virus ini.

2. Melakukan penyuluhan memakai masker yang benar

${ }^{5}$ Ni Made Nopita Wati et al., "Optimalisasi Penggunaan Alat Perlindungan Diri (APD) Pada Masyarakat Dalam Rangka Mencegah Penularan Virus COVID-19,” Jurnalempathy.Com 1, no. 1 (2020): 1-8.

${ }^{6}$ Santy Irene Putri, "Studi Literatur: Efektivitas Penggunaan Masker Kain Dalam Pencegahan Transmisi Covid-19,” Jurnal Kesehatan Manarang 6, no. khusus (2020): 10. 


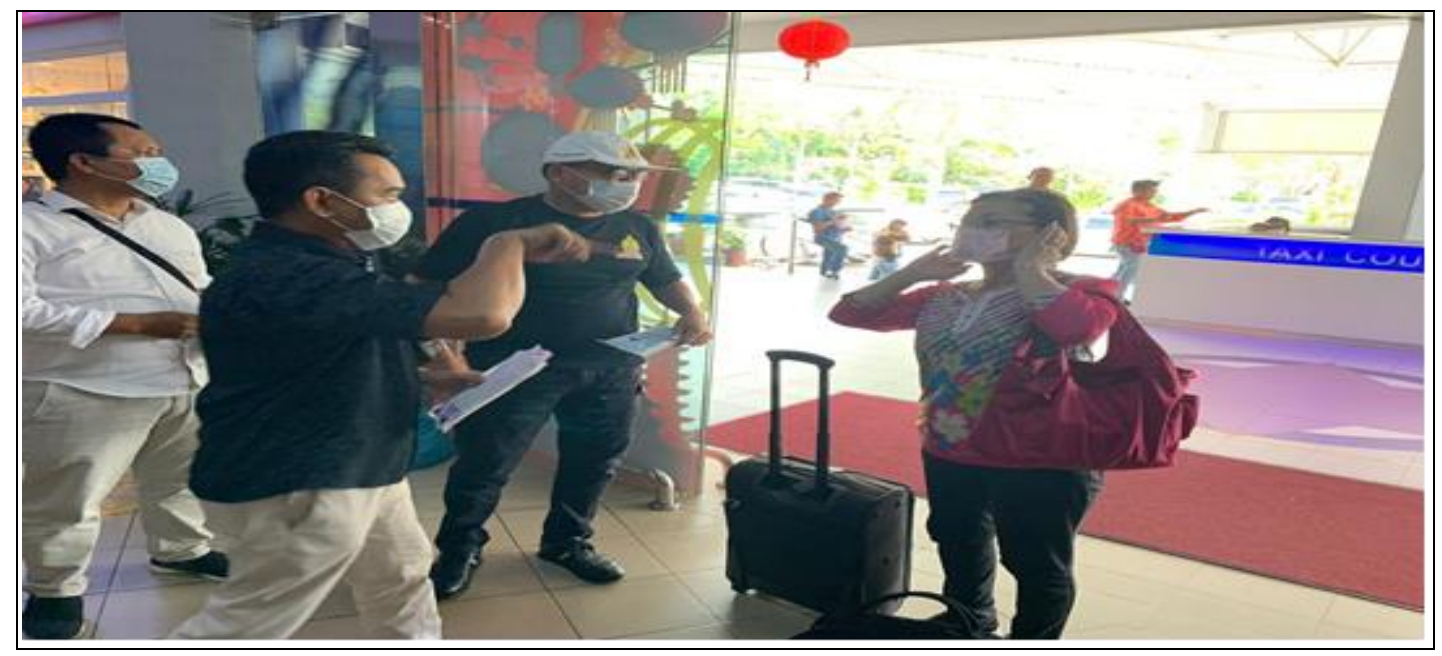

Gambar 3. Foto Tim memberikan edukasi pemakaian masker yang benar

Kegiatan ini bertujuan agar masyarakat mengetahui cara memakai masker yang benar. Kegiatan ini dilakukan karena banyak sekali ditemukan masyarakat yang memakai masker dengan cara yang salah. Beberapa dari mereka memakai masker tidak menutupi hidung, ada yang menariknya sampai di bawah dagu, sebagian juga memakai maskernya terbalik, dan masih banyak lagi cara-cara memakai masker yang salah yang ditemukan tim di lokasi pelaksanaan pengabdian masyarakat.

Memakai masker dengan benar merupakan salah satu kunci dari kesuksesan upaya pencegahan penyebaran virus Covid-19. Karena masyarakat yang memakai masker tetapi dengan caracara yang disebut di atas, maka kemungkinan terkena virus ini tetap besar. Menurut tim LSM Peduli Bangsa, mereka juga melihat beberapa masyarakat yang membuka maskernya dan menyentuh hidung dan mulut mereka dengan tangan yang belum dicuci.

Oleh karena itu, tim dari pengabdian ini juga melakukan edukasi kepada mereka yang menerima masker gratis ini tentang bagaimana cara memakai masker yang benar agar bisa terhindar dari penularan virus Covid-19. Tidak hanya itu, tim juga menyampaikan kepada masyarakat yang menerima masker gratis apa yang boleh dan tidak boleh dilakukan saat memakai masker. Aktifitas seperti ini menurut Fay sangat perlu diberi edukasi dan penyeluhan kepada masyarakat pentingnya menggunakan masker serta cara memakai masker yang baik ${ }^{7}$.

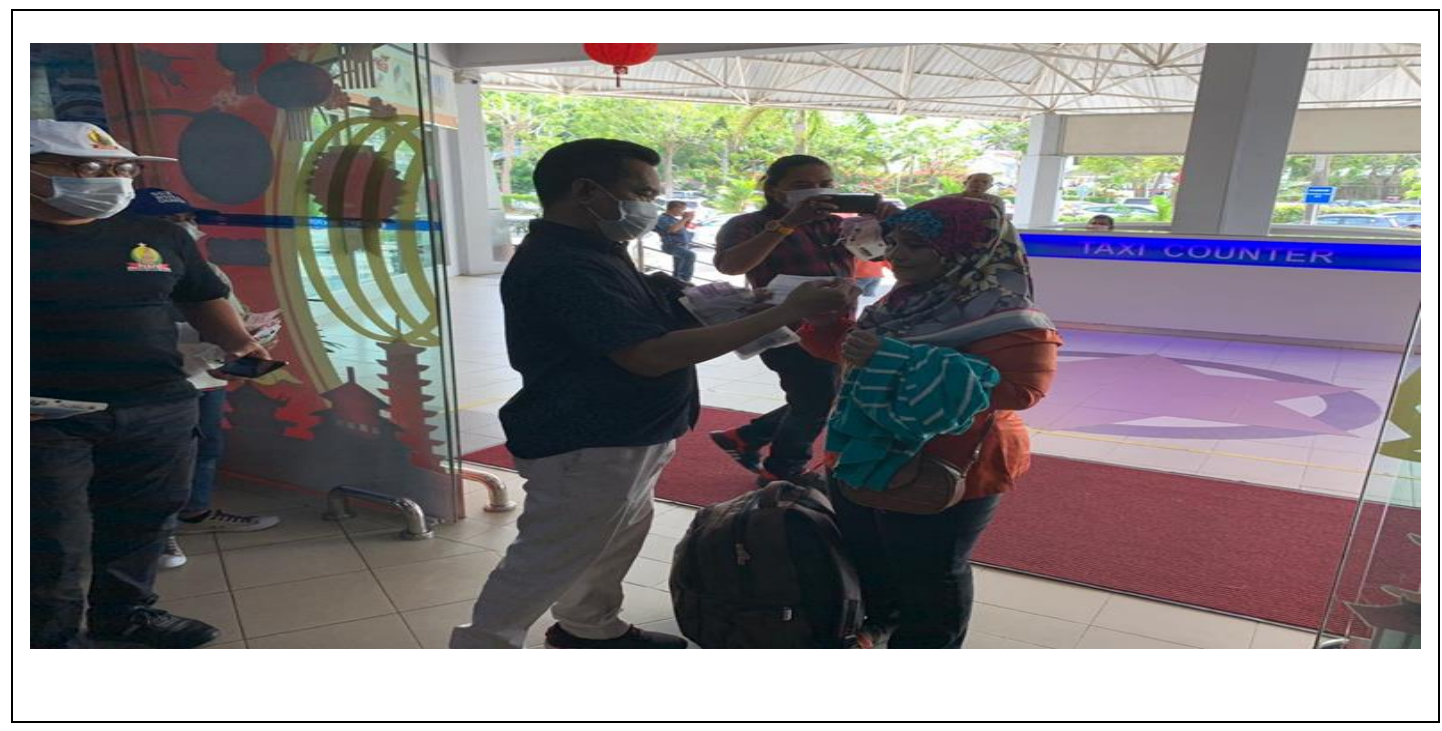

Gambar 4. Foto tim membantu memakaikan masker dengan benar

${ }^{7}$ Daniel Lenox Fay, "PEMBERDAYAAN MASYARAKAT DALAM PENGGUNAAN MASKER NONMEDIS SEBAGAI UPAYA PREVENTIF PENULARAN COVID-19," Angewandte Chemie International Edition, 1, no. 2 (2019): 951-952. 


\section{SIMPULAN}

Pelaksanaan kegiatan bakti sosial pembagian masker gratis dan edukasi memakai masker dengan benar ini telah berjalan dengan baik sesuai dengan tujuan dari pengabdian masyarakat. Hasil dari kegiatan ini meringankan beban masyarakat yang ada di lokasi untuk memiliki masker serta mereka menjadi terlatih untuk memakai masker dengan benar. Yang tidak kalah penting adalah meningkatnya kesadaran masyarakat untuk lebih waspada terhadap virus Covid-19. Maka dari itu melalui kegiatan pembagian masker ini diharapkan pencegahan penularan virus ini dapat dioptimalkan oleh masyarakat, khususnya yang ada di PFBC.

Pada kesempatan ini, LSM Peduli Bangsa mengucapkan terima kasih kepada PWI dan PERPAT yang telah bekerja sama dengan baik serta kepada pimpinan PFBC yang telah memberikan izin kegiatan pengabdian masyarakat ini sehingga dapat terlaksana.

\section{DAFTAR PUSTAKA}

Atmojo, Joko Tri, Sri Iswahyuni, Rejo Rejo, Catur Setyorini, Kiki Puspitasary, Heni Ernawati, Ahmad Rois Syujak, et al. "Penggunaan Masker Dalam Pencegahan Dan Penanganan Covid-19: Rasionalitas, Efektivitas, Dan Isu Terkini." Avicenna : Journal of Health Research 3, no. 2 (2020): 84-95.

Fay, Daniel Lenox. "PEMBERDAYAAN MASYARAKAT DALAM PENGGUNAAN MASKER NONMEDIS SEBAGAI UPAYA PREVENTIF PENULARAN COVID-19." Angewandte Chemie International Edition, 1, no. 2 (2019): 951-952.

Organization, World Health. Statement on the Second Meeting of the International Health Regulations (2005) Emergency Committee Regarding the Outbreak of Novel Coronavirus (2019-NCoV). Geneva, 2020. https://www.who.int/news/item/30-01-2020-statement-on-the-second-meeting-ofthe-international-health-regulations-(2005)-emergency-committee-regarding-the-outbreak-ofnovel-coronavirus-(2019-ncov).

Putri, Santy Irene. "Studi Literatur: Efektivitas Penggunaan Masker Kain Dalam Pencegahan Transmisi Covid-19.” Jurnal Kesehatan Manarang 6, no. khusus (2020): 10.

Rozie, Fachrur. "Virus Corona Di Indonesia, Harga Masker Melonjak Hingga Rp 1,5 Juta." LIputan6.Com. Jakarta, 2020. https://www.liputan6.com/news/read/4192648/virus-corona-diindonesia-harga-masker-melonjak-hingga-rp-15-juta.

Sinuhaji, Julkifli. "Update Virus Corona per 5 Februari 2020, Korban Meninggal Capai 492 Orang." Pikiran Rakyat.Com. Jakarta, 2020. https://www.pikiran-rakyat.com/internasional/pr01337139/update-virus-corona-per-5-februari-2020-korban-meninggal-capai-492-orang.

Wati, Ni Made Nopita, Ni Kadek Yuni Lestari, Desak Made Ari Dwi Jayanti, and Nyoman Sudarma. "Optimalisasi Penggunaan Alat Perlindungan Diri (APD) Pada Masyarakat Dalam Rangka Mencegah Penularan Virus COVID-19.” Jurnalempathy.Com 1, no. 1 (2020): 1-8. 